\title{
Observations of massive air-pollution transport and associated air quality in the Yellow Sea region
}

\author{
Y. S. Chung • H. S. Kim
}

Received: 30 November 2007 / Accepted: 7 August 2008 / Published online: 30 September 2008

(C) The Author(s) 2008. This article is published with open access at Springerlink.com

\begin{abstract}
Presently, China is the world's second largest energy consumer, and it generates extensive atmospheric emissions in the Yellow Sea region in East Asia. In the westerly region, the downwind effect creates large-scale transport of air pollution and significantly impacts on air quality semiperiodically in Korea, Japan, and the western Pacific Ocean. Observations with satellite and ground measurements of regional air quality show the movements and impact of anthropogenic and natural origins of air pollution in the Yellow Sea region. Fifteen air-pollution cases were recorded from January to September 2007. These are the basis for our findings on regional-scale transport of air pollution and variations of air quality in Korea and SW Japan. Impacts on air quality and health are included.
\end{abstract}

Keywords Air pollution - Air quality measurements .

Satellite observations · Dust loadings · Long-range transport . Yellow Sea air quality

\section{Introduction}

Western Europe, eastern North America, and East Asia, the three major industrial regions of the world, are major emission

\section{Y. S. Chung $(\bowtie) \cdot$ H. S. Kim}

Korea Centre for Atmospheric Environment Research (KCAER),

Khangnae,

Cheongwon-Cheongju 363-891, Korea

e-mail: kccar1@kornet.net

H. S. Kim

e-mail: envir007@chol.com

H. S. Kim

Korea National University of Education/KCAER,

Khangnae,

Cheongwon-Cheongju 363-891, Korea sources of air pollution (AP) and greenhouse gases (GHG). In East Asia, the fossil fuel consumption in 2005 for the three major countries of China, Japan, and Korea was 1,554M, $525 \mathrm{M}$, and 225M tons, respectively (Yearbook 2006). These three alone use $21.8 \%$ of the world's energy, adding AP and GHG to the atmosphere and causing environmental impacts, which include global warming and climate change (Chung et al. 2004). Strikingly, it has been reported that in heavily polluted China, the poor air and water quality affect about 1 million of the 20 million babies born each year, with about 300,000 babies suffering from visible deformities (AFP 2007). According to a World Bank study, each year, about 460,000 people in China die prematurely because of air and water pollution (Reuters 2007).

In September 2007, leaders from the United Nations and the Asia Pacific Economic Cooperation declared that resolution of atmospheric emission and climate change was the world's top-priority issue. Meanwhile, the emission inventory of AP and GHG provides important input into regional and global numerical models of AP and GHG (Crutzen 2002; Seinfeld et al. 2004), and observational data are needed to verify numerical outputs. Relatively little is known from the literature on observations of extensive transport of AP in the Yellow Sea region.

Measurements of AP in central Korea have been carried out, and satellite observations of extensive AP masses over the Yellow Sea region are also made routinely. In the present study, observed data from January to September 2007 are used. Both qualitative and quantitative analyses of 15 episodes resulting from long-range transport of AP are presented. The purpose of this paper is also to discuss the results of satellite observations of massive AP over the Yellow Sea region and associated ground measurement of air pollutant concentrations downstream in the Korean Peninsula and SW Japan. 
Table 1 Hourly minimum (Hmin) concentrations of air quality with the clean air and daily low concentrations of air quality observed at Cheongwon (KCAER) during 5 days with the clean Pacific air

\begin{tabular}{|c|c|c|c|c|c|c|c|c|c|c|c|c|}
\hline $\begin{array}{l}\text { Year } \\
\text { (unit) }\end{array}$ & $\mathrm{M}$ & $\mathrm{D}$ & Hours & $\begin{array}{l}\text { VIS } \\
(\mathrm{km})\end{array}$ & $\begin{array}{l}\text { TSP } \\
\left(\mu \mathrm{g} / \mathrm{m}^{3}\right)\end{array}$ & $\begin{array}{l}\text { PM10 } \\
\left(\mu \mathrm{g} / \mathrm{m}^{3}\right)\end{array}$ & $\begin{array}{l}\text { PM2.5 } \\
\left(\mu \mathrm{g} / \mathrm{m}^{3}\right)\end{array}$ & $\begin{array}{l}\mathrm{O}_{3} \\
(\mathrm{ppb})\end{array}$ & $\begin{array}{l}\text { NO } \\
(\mathrm{ppb})\end{array}$ & $\begin{array}{l}\mathrm{NO}_{2} \\
(\mathrm{ppb})\end{array}$ & $\begin{array}{l}\mathrm{CO} \\
(\mathrm{ppb})\end{array}$ & $\begin{array}{l}\mathrm{SO}_{2} \\
\text { (ppb) }\end{array}$ \\
\hline Hmin & - & - & 1 & 0.1 & 16.0 & 5.0 & 1.0 & 0.0 & 0.0 & 0.0 & 90.0 & 0.0 \\
\hline 2007 & 8 & 11 & 24 & 11.9 & 28.9 & 17.6 & 8.4 & 21.2 & 4.1 & 5.7 & 215.0 & 0.3 \\
\hline 2007 & 8 & 12 & 24 & 14.5 & 23.8 & 11.4 & 5.7 & 17.5 & 0.0 & 3.0 & 144.5 & 0.5 \\
\hline 2007 & 8 & 13 & 24 & 11.9 & 25.2 & 13.6 & 6.1 & 17.8 & 0.4 & 3.8 & 148.5 & 0.0 \\
\hline 2007 & 8 & 16 & 24 & 15.0 & 33.1 & 20.6 & 9.2 & 16.1 & 1.8 & 8.1 & 141.3 & 1.1 \\
\hline 2007 & 9 & 2 & 24 & 3.5 & 17.3 & 6.5 & 3.3 & 35.2 & 0.3 & 5.0 & 267.4 & 0.5 \\
\hline Ave & - & - & - & 11.4 & 25.7 & 13.9 & 6.5 & 21.6 & 1.3 & 5.1 & 183.3 & 0.5 \\
\hline
\end{tabular}

\section{Regional background concentrations}

Since 1990, we have been monitoring AP at the Korea Centre for Atmospheric Environment Research (KCAER), which is a regional background site in Cheongwon-Cheongju in central Korea, and GHG are being monitored at the western tip of central Korea in collaboration with the National Oceanic and Atmospheric Administration (NOAA) in Boulder, USA.

The routine and real-time measurements of AP, GHG, and weather elements with satellite observations are carried out at the present research center (KCAER). Table 1 lists hourly minimum (Hmin) and daily average values of carbon monoxide $(\mathrm{CO})$ and other AP and visibility observed on five relatively clean days in summer at the rural site of KCAER in Cheongwon, $120 \mathrm{~km}$ south of Seoul. In foggy conditions, visibility goes down to less than $0.1 \mathrm{~km}$, and on smoggy and hazy days, visibility down to $2-3 \mathrm{~km}$ is commonly observed.
When a new and intense anticyclone arrives, and after heavy and steady rainfall, gaseous pollutants, including ozone $\left(\mathrm{O}_{3}\right)$, nitric oxide $(\mathrm{NO})$, nitric dioxide $\left(\mathrm{NO}_{2}\right)$, and sulfur dioxide $\left(\mathrm{SO}_{2}\right)$, are generally found in detectably low concentrations with $\mathrm{CO}$ value at about 90 parts per billion (ppb). This CO level is the same low level observed at Mauna Loa, Hawaii (Tans and White 1998). On a clean day, the lowest observed hourly dust concentrations are total suspended particulates (TSP) at $16.0 \mathrm{\mu gm}^{-3}$, particular matter less than $10 \mu \mathrm{m}$ in diameter known as PM10 at $5.0 \mu \mathrm{gm}^{-3}$, and PM2.5 at $1.0 \mathrm{\mu gm}^{-3}$. At the same time, these dust particles have background-level concentrations in Cheongwon. These measurements were made by KCAER.

On the other hand, the daily average values of dust loadings in summer are TSP at $25.7 \mu \mathrm{gm}^{-3}, \mathrm{PM} 10$ at $13.9 \mathrm{\mu gm}^{-3}$, and PM2.5 at $6.5 \mathrm{\mu gm}^{-3}$. The observed daily $\mathrm{O}_{3}$ on clean days is less than $21.6 \mathrm{ppb}$, albeit hourly $\mathrm{O}_{3}$ concentrations

Table 2 Hourly maximum concentrations of air pollutants and meteorological parameters observed at Cheongwon (KCAER) in central Korea for 15 episode cases from January to September 2007

\begin{tabular}{|c|c|c|c|c|c|c|c|c|c|c|c|c|c|c|}
\hline $\begin{array}{l}\text { Case } \\
\text { number }\end{array}$ & Date & $\begin{array}{l}\text { TSP } \\
\left(\mu \mathrm{g} / \mathrm{m}^{3}\right)\end{array}$ & $\begin{array}{l}\text { PM10 } \\
\left(\mu \mathrm{g} / \mathrm{m}^{3}\right)\end{array}$ & $\begin{array}{l}\text { PM2.5 } \\
\left(\mu \mathrm{g} / \mathrm{m}^{3}\right)\end{array}$ & $\begin{array}{l}\mathrm{O}_{3} \\
(\mathrm{ppb})\end{array}$ & $\begin{array}{l}\text { NO } \\
(\mathrm{ppb})\end{array}$ & $\begin{array}{l}\mathrm{NO}_{2} \\
(\mathrm{ppb})\end{array}$ & $\begin{array}{l}\mathrm{CO} \\
(\mathrm{ppb})\end{array}$ & $\begin{array}{l}\mathrm{SO}_{2} \\
(\mathrm{ppb})\end{array}$ & $\begin{array}{l}\text { VSBY } \\
(\mathrm{km})\end{array}$ & $\begin{array}{l}T_{\max } \\
\left({ }^{\circ} \mathrm{C}\right)\end{array}$ & $\mathrm{Wd}$ & $\begin{array}{l}\text { Ws } \\
(\mathrm{m} / \mathrm{s})\end{array}$ & Traj* \\
\hline 1 & Jan 17 & 157 & 144 & 105 & 24 & 52 & 45 & 1,207 & 22 & 1.4 & 5.4 & NW & 1.7 & W \\
\hline 2 & Jan 23 & 183 & 174 & 138 & 11 & 122 & 67 & 1,550 & 18 & 0.8 & 5.1 & NW & 1.4 & $\mathrm{~N}$ \\
\hline 3 & Feb 4 & 189 & 128 & 67 & 28 & 5 & 19 & 746 & 5 & 6.1 & 10.5 & WNW & 1.6 & NW \\
\hline 4 & Feb 6 & 156 & 147 & 95 & 39 & 48 & 49 & 1,060 & 6 & 2.9 & 14.0 & WNW & 1.4 & W \\
\hline 5 & Feb 10 & 108 & 93 & 76 & 43 & 1 & 19 & 1,025 & 10 & 2.5 & 7.3 & W & 3.4 & W \\
\hline 6 & Feb 22 & 158 & 152 & 133 & 67 & 111 & 57 & 1,343 & 5 & 2.3 & 13.6 & SW & 2.2 & W \\
\hline 7 & Mar 15 & 164 & 148 & 95 & 93 & 1 & 15 & 1,077 & 16 & 7.6 & 15.1 & NW & 1.8 & WNW \\
\hline 8 & Mar 25 & 183 & 157 & - & 89 & 0 & 5 & 1,060 & 8 & 3.8 & 15.5 & WSW & 3.8 & WNW \\
\hline 9 & Mar 26 & 112 & 105 & - & 54 & 2 & 28 & 1,162 & 6 & 2.3 & 12.3 & NW & 1.6 & W \\
\hline 10 & Mar 27 & 240 & 215 & 109 & 78 & 1 & 11 & 895 & 6 & 1.0 & 14.9 & SW & 3.6 & WSW \\
\hline 11 & May 27 & 332 & 295 & 128 & 128 & 0 & 0 & 892 & 18 & 5.1 & 27.7 & SW & 2.5 & WSW \\
\hline 12 & Jun 20 & 81 & 59 & 43 & 134 & 1 & 18 & 369 & 5 & 9.0 & 29.5 & WNW & 1.4 & S \\
\hline 13 & Jul 18 & 109 & 99 & 80 & 92 & 2 & 10 & 439 & 3 & 7.8 & 30.9 & WSW & 0.3 & WSW \\
\hline 14 & Jul 29 & 160 & 152 & 131 & 77 & 65 & 11 & 410 & 4 & 2.0 & 28.6 & WSW & 1.7 & WSW \\
\hline 15 & Sep 11 & 156 & 138 & 109 & 106 & 0 & 3 & 1,049 & 11 & 3.8 & 27.5 & SW & 0.8 & W \\
\hline Ave & - & 166 & 147 & 87 & 71 & 27 & 24 & 952 & 10 & 4 & - & - & - & - \\
\hline
\end{tabular}

* A general direction of air-parcel trajectories is included. 
go down to 0 after steady rain. The daily average values on clean days are 1.3, 5.1, and $0.5 \mathrm{ppb}$ for $\mathrm{NO}, \mathrm{NO}_{2}$, and $\mathrm{SO}_{2}$, respectively. Meanwhile, the daily minimum level of $\mathrm{CO}$, a toxic pollutant and a GHG, is at $183.3 \mathrm{ppb}$. These minimum concentrations of AP are compared in this paper with the hourly maximum concentrations observed in Cheongwon during AP episodes.

\section{Air-pollution episodes}

Table 2 includes air quality data with weather elements measured at KCAER during 15 AP episodes, which occurred from January to September 2007. Measured concentrations of dust, $\mathrm{O}_{3}, \mathrm{NO}, \mathrm{NO}_{2}, \mathrm{CO}$, and $\mathrm{SO}_{2}$ are shown with the visibility and satellite data observed (KCAER) at the time of
Fig. 1 a A satellite image showing the extent of air pollution plume (magenta) over the Yellow Sea - Korean Peninsula - Korean East Sea (1135 LST, 17 January 2007). b Hourly concentrations of TSP, PM10, PM2.5 and CO with visibility observed at KCAER in Cheongwon in central Korea in 15-18 January 2007 a

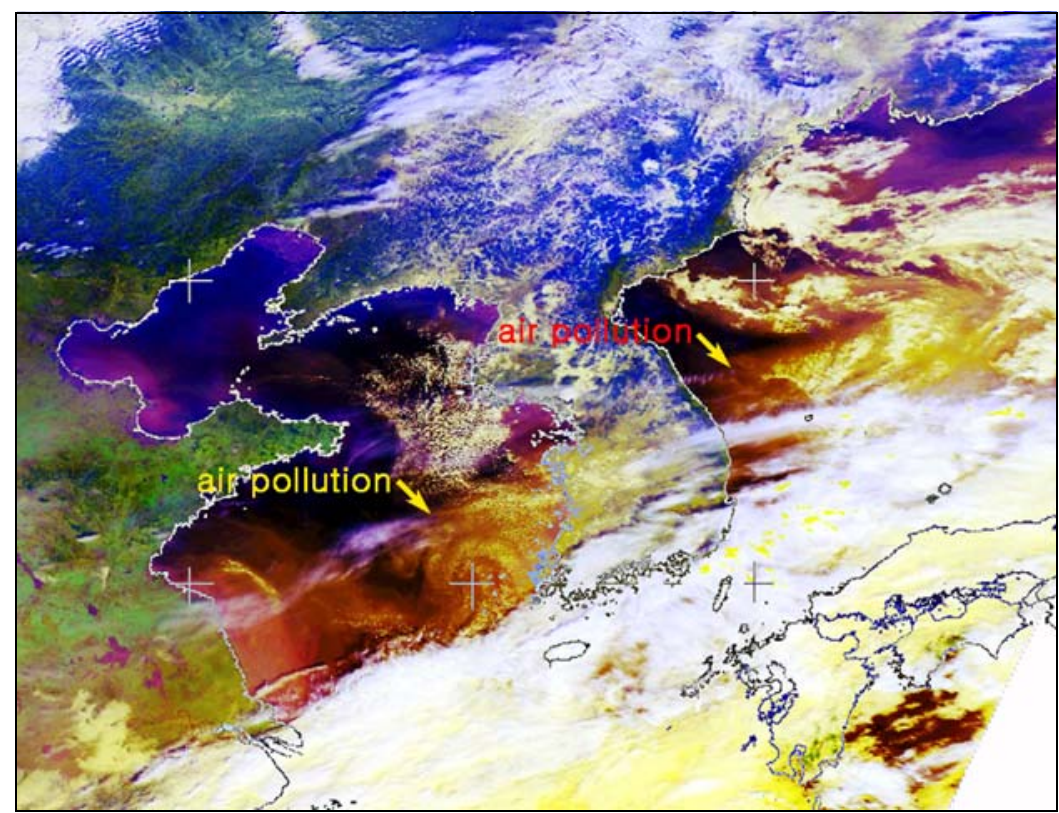

b
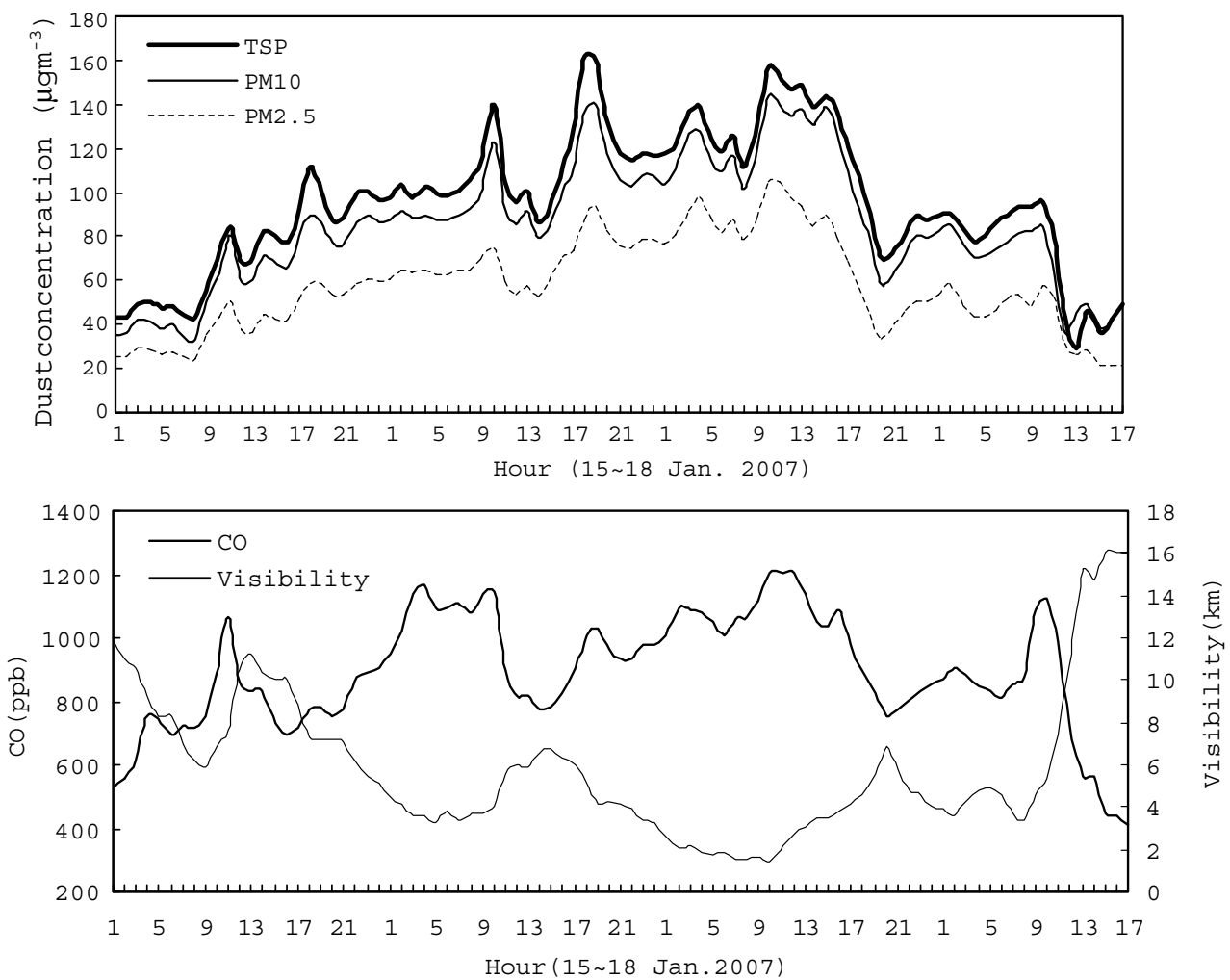
elevated AP. Maximum air temperature, wind direction, wind speed, and the general direction of air-parcel trajectories are also included in Table 2.

For all 15 episodes, the average concentrations of TSP,

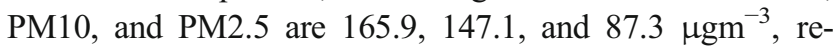
spectively. These are relatively high compared with the air quality standard of the USA. The rate between hourly maximum TSP and PM10 is $88.2 \%$ and between hourly maximum TSP and PM2.5 is $59.0 \%$, and these are the typical rates associated with industrial AP.

$\mathrm{O}_{3}$ values are generally low in cold seasons. Relatively high values of $\mathrm{O}_{3}$ in excess of $80 \mathrm{ppb}$ were observed for episodes $7,8,11,12,13$, and 15. Although the observed background value of $\mathrm{CO}$ is $90 \mathrm{ppb}$, as measured at Mauna Loa, Hawaii (Tans and White 1998), CO concentrations of 369-1,550 ppb have been observed at KCAER during the AP episodes.

On 16 January 2007, an anticyclone over northern China was weakening, and air temperature in Korea was rising. Meanwhile, AP accumulated over the Yellow Sea was moving into the Korean Peninsula and onward to the Korea East Sea. The measured concentrations of AP at KCAER and at other stations as well were relatively high. The satellite image of 17 January shown in Fig. 1a shows clear evidence of a mass of polluted cloud (in magenta or reddish-brown), which was over the Yellow Sea and South Korea and extended as far as the Korea East Sea. The length of the Korean Peninsula is approximately 1,000 km. Meanwhile, the same method of air pollution detection by satellite data used in earlier studies (Al-Saadi et al. 2005; Chung 1986; Chung and Le 1984) was employed. In the satellite observations, Channel 1 (0.58-0.68 $\mu \mathrm{m})$, Channel 2 (0.73$1.00 \mu \mathrm{m})$, and Channel $4(10.3-11.30 \mu \mathrm{m})$ of NOAA data were utilized for false-color composite analysis.

The daytime levels of AP measured by the Ministry of the Environment and provincial agencies were also generally high. Maximum hourly concentrations of AP observed at KCAER in Cheongwon were also high, as shown in Table 2: TSP at $157 \mu \mathrm{gm}^{-3}$, PM10 at $144 \mu \mathrm{gm}^{-3}$ and PM2.5 at $105 \mathrm{\mu gm}^{-3}$, NO at $52 \mathrm{ppb}, \mathrm{NO}_{2}$ at $45 \mathrm{ppb}, \mathrm{CO}$ at 1,207 ppb, and $\mathrm{SO}_{2}$ at $22 \mathrm{ppb}$. AP levels in Fig. $1 \mathrm{~b}$ showed an increasing trend, while visibility decreased with time to $1.4 \mathrm{~km}$. During the winter day, maximum air temperature rose to $5.4^{\circ} \mathrm{C}$ with a weak NW wind. The air-parcel trajectories of the Hybrid Single-Particle Lagrangian Integrated Trajectory model (Draxler and Rolph 2003) and of another NOAA model (J Harris) also indicated westerly airflows, which took fewer than 3 days to reach Korea (Fig. 2). Trajectories were all calculated for 3 days.

Figure 2 illustrates the air-parcel trajectories ending at Cheongwon (C) in central Korea for 12 episodes. Clearly, westerly winds and airflows must have been present to bring AP to central Korea from the Yellow Sea and China. In all episodes, air-pollutant plumes from the Yellow Sea were transported to the Korean Peninsula to impact on air quality. For case 12 (k in Fig. 2), the calculated trajectory for 3 days shows that air parcels were coming from Kyushu, SW Japan; however, for the fourth and fifth days, it was moving via the
Fig. 2 Air-parcel trajectories arriving at Cheongwon $(C)$ in central Korea for 12 cases

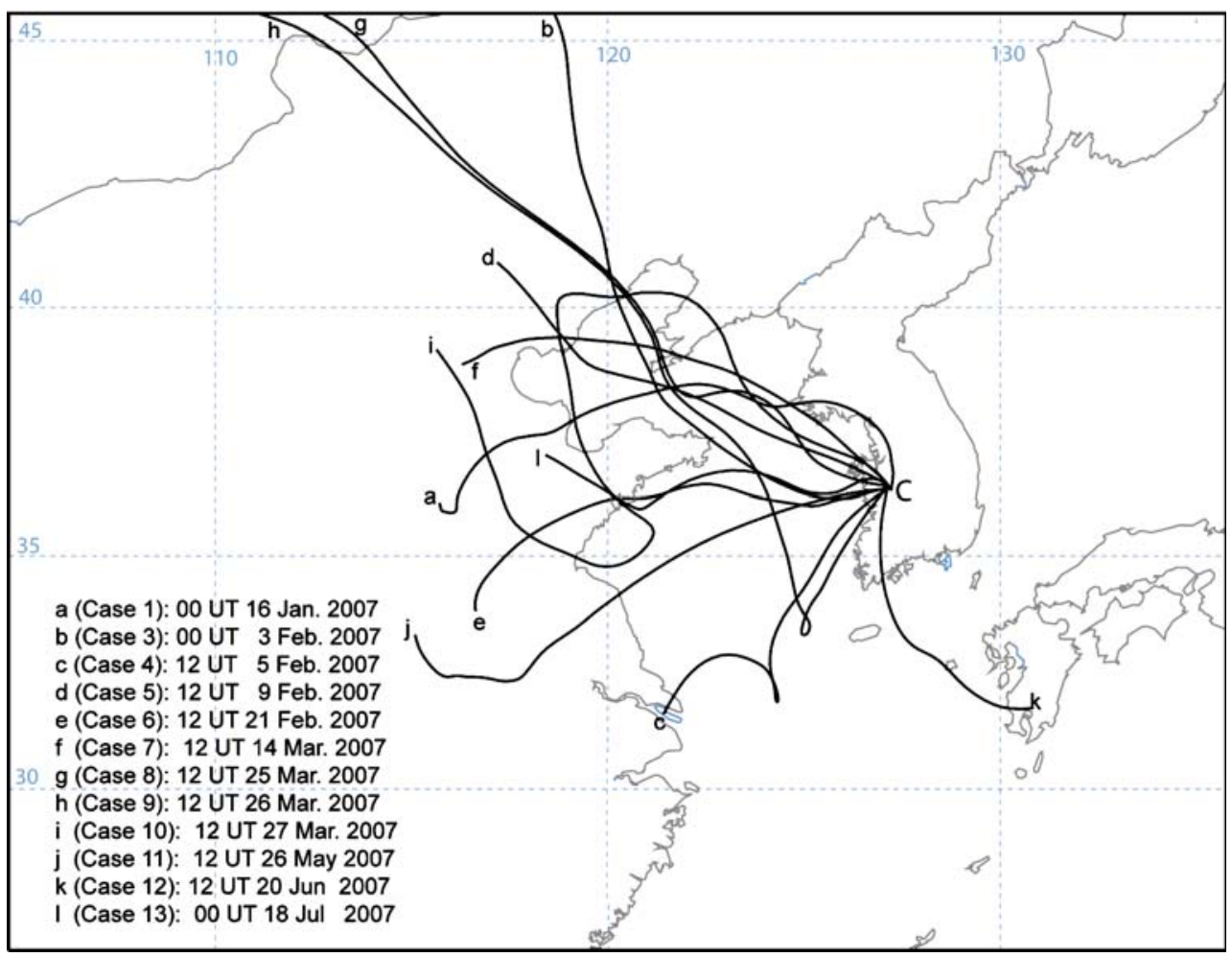


Fig. 3 Hourly concentrations of TSP, PM10, PM2.5, and CO with visibility observed at Cheongwon in central Korea: a For 21-24 January 2007; b for 3-4 February; c for 5-7 February; d for 21-23 February; e for 24-27 March; $\mathbf{f}$ for 10-12 September a
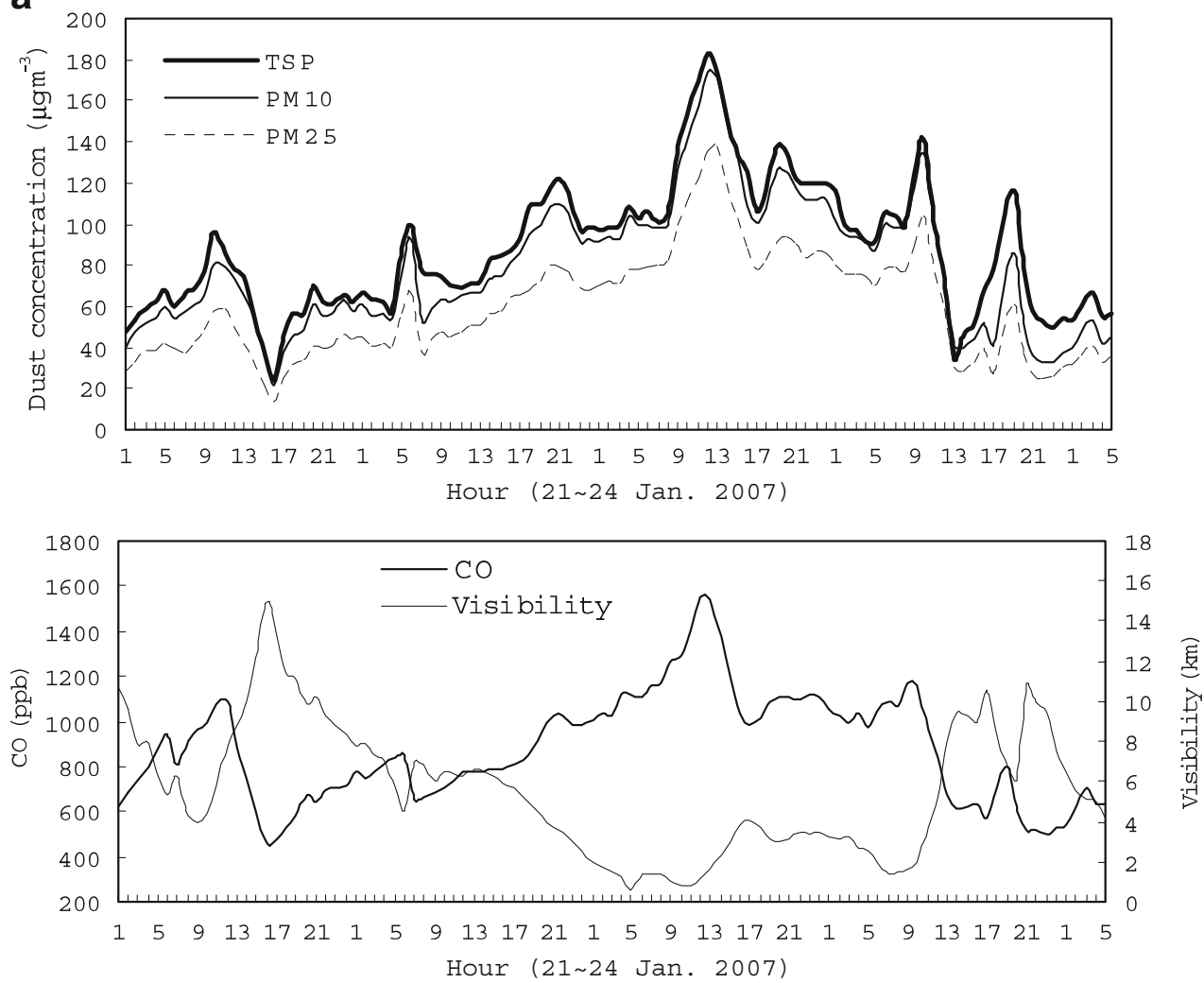

b
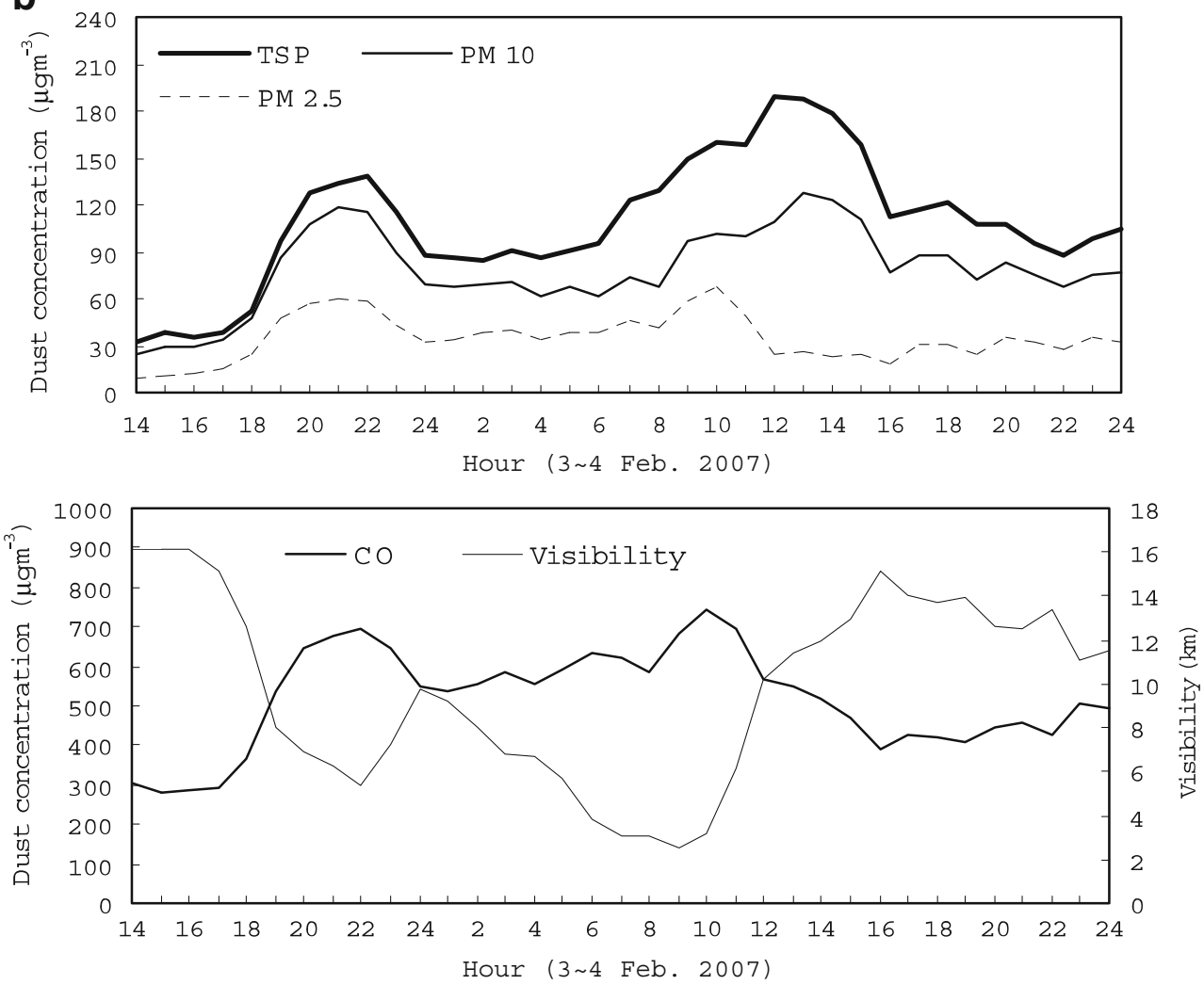
Fig. 3 (continued)
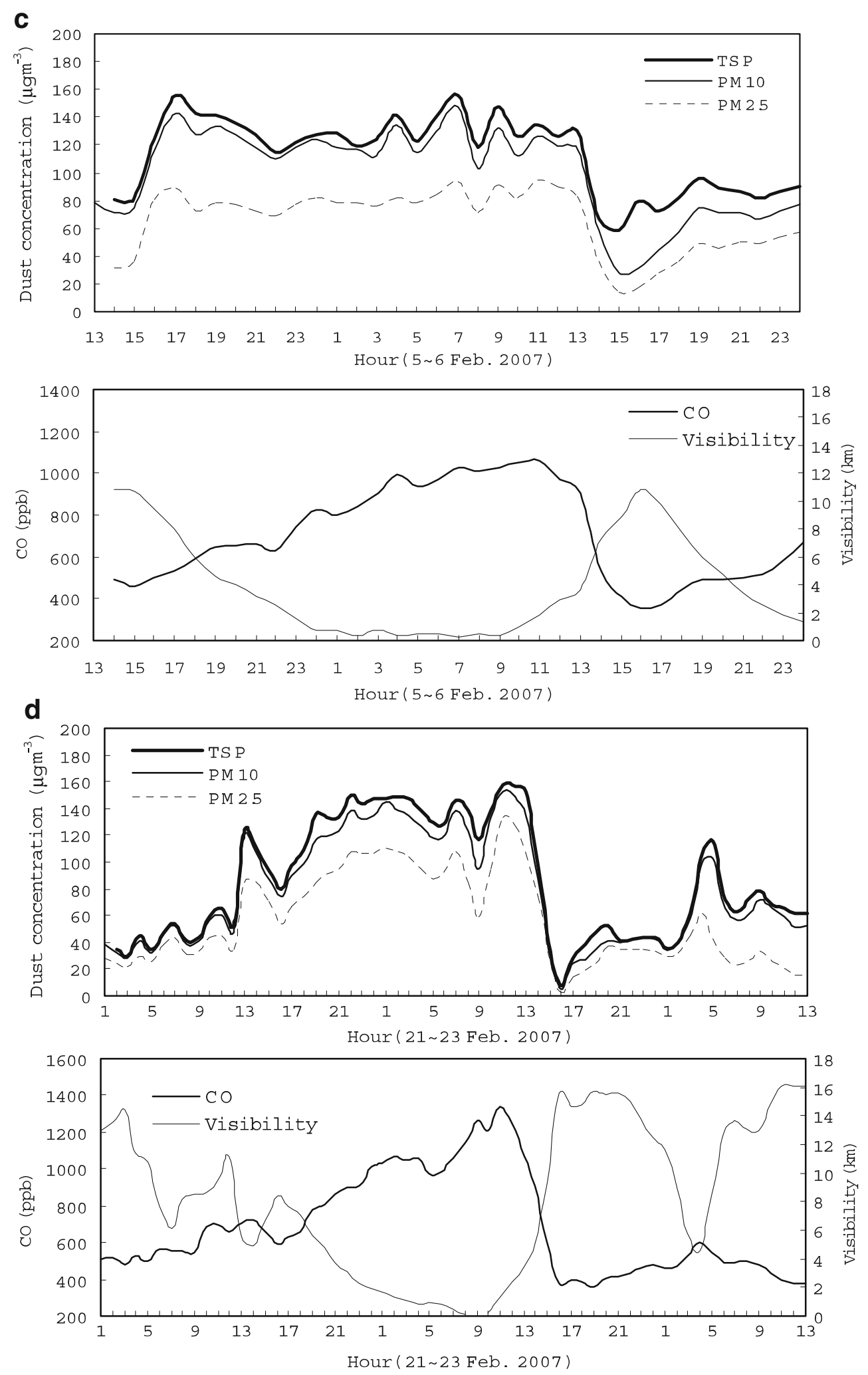

East Sea off Taiwan (not shown). For this reason, dust loadings were less than in other cases, while observed concentrations of ozone at Cheongwon on 20 June 2007 were as high as $134 \mathrm{ppb}$.
The distance of the Yellow Sea from the west coast of Korea to China is approximately $300-700 \mathrm{~km}$. With weak to moderate winds and airflows $\left(2-5 \mathrm{~m} \mathrm{~s}^{-1}\right)$, anthropogenic AP takes between 17 hours and 4 days to cross the Yellow Sea. 
Fig. 3 (continued)
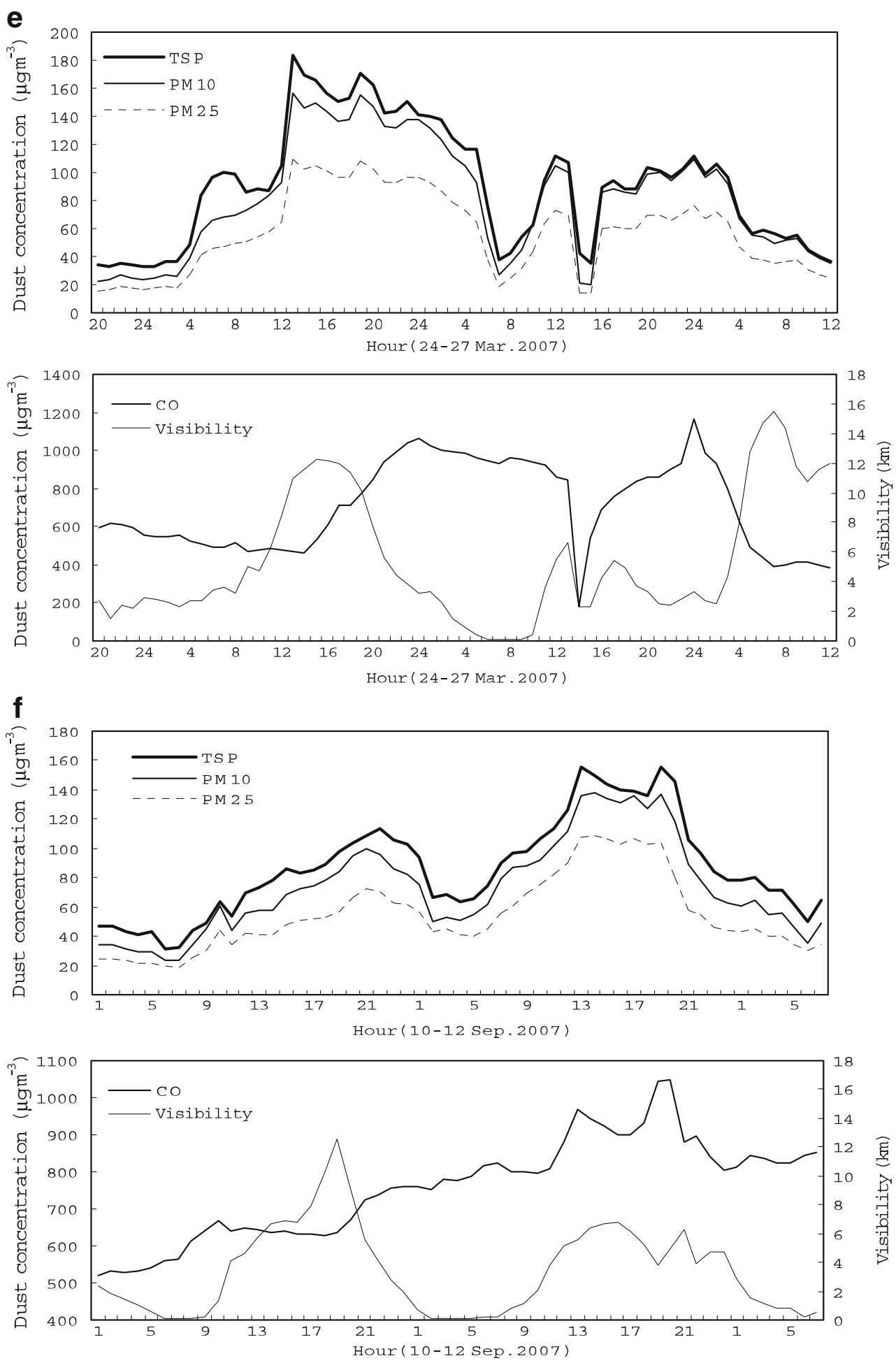

These distances are favorable for the chemical transformation of aerosols and other gaseous pollutants in the moist air of the Yellow Sea.

According to the satellite image shown in Fig. 4a, an extensive AP mass was apparently moving into the Korean Peninsula from 22 January. The elevated hourly concentrations of TSP, PM10, PM2.5, CO, and visibility were observed at Cheongwon on 23 January (Fig. 3a). These increased values may be compared with the fresh air concentrations of each AP in Table 1. The hourly maximum concentration of TSP was $183 \mu \mathrm{gm}^{-3}$, while values of PM10 and PM2.5 in the anthropogenically polluted air were 174 and $138 \mu^{-3} \mathrm{gm}^{-3}$, respectively. PM10 and PM2.5 concentrations were also generally high compared with TSP concentrations in the 

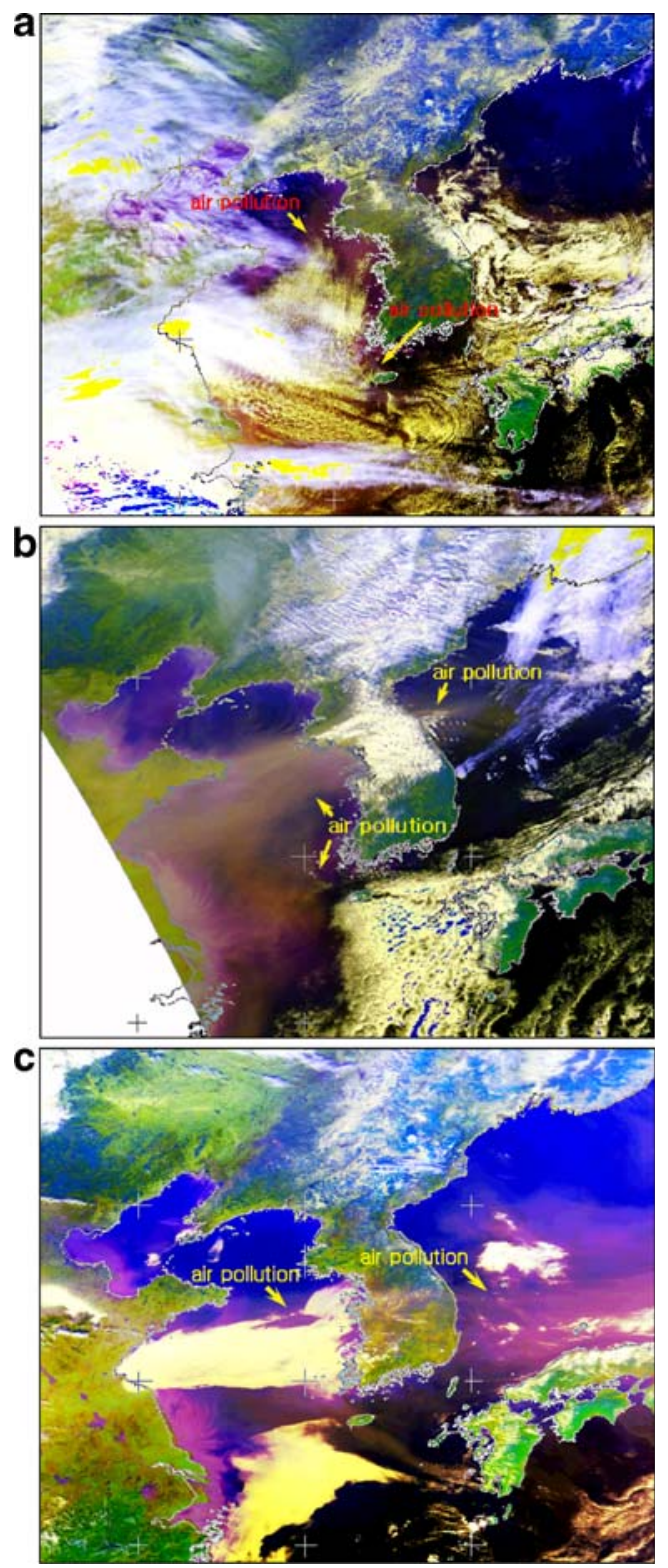

Fig. 4 Satellite images showing massive air pollution (magenta, or reddish brown) plumes over the Yellow Sea: a for 1325 LST, 22 January; b for 1302 LST, 03 February; c for 1412 LST, 06 February; d for 1317 LST, 21 February; e for 1042 LST, 23 February; f for 1250 LST, 25 March; $\mathbf{g}$ for 1144 LST, 27 March; $\mathbf{h}$ for 1127 LST, 27 May; i for 1027 LST, 11 September

anthropogenically polluted air. In contrast, the ratios of TSP and PM10 and TSP and PM2.5 are generally much lower in a wind-blown dust storm (Chung et al. 2003a, b). CO values were high, and visibility was even less than 1-2 km during the AP episode. Consequently, observed AP in Cheongwon was many times higher than the measured regional background concentrations (Table 1).

Figure $4 \mathrm{~b}$ shows a satellite image from 3 February. The extensive, large-scale transport of AP over the Yellow Sea traveled as far as central Korea. The massive plume of
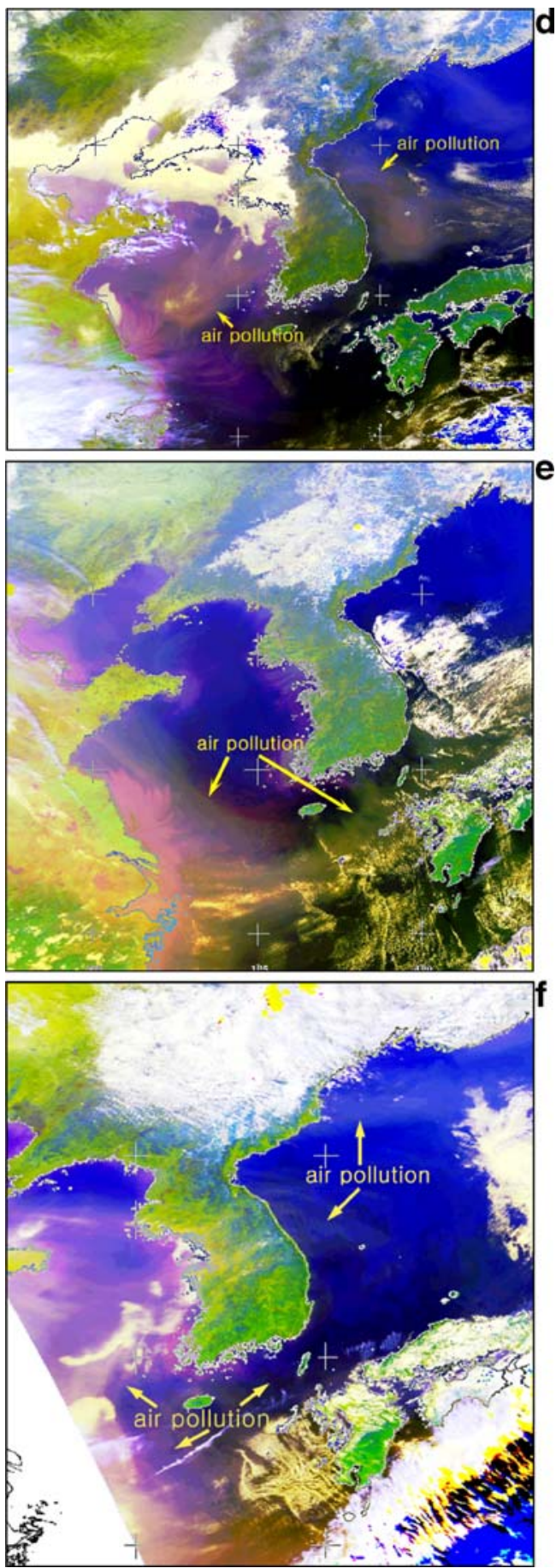

Fig. 4 (continued)

pollutants resulted in relatively high levels of PM10 and PM2.5 compared with TSP concentration and high concentration of $\mathrm{CO}$ at $746 \mathrm{ppb}$ (Fig. 3b). Concentrations of AP were also high on 3 February, followed by even higher levels on 4 February.

Figure $4 \mathrm{c}$ shows case 4 (c in Fig. 2), where, on 6 February, a massive AP plume from the Yellow Sea passed 

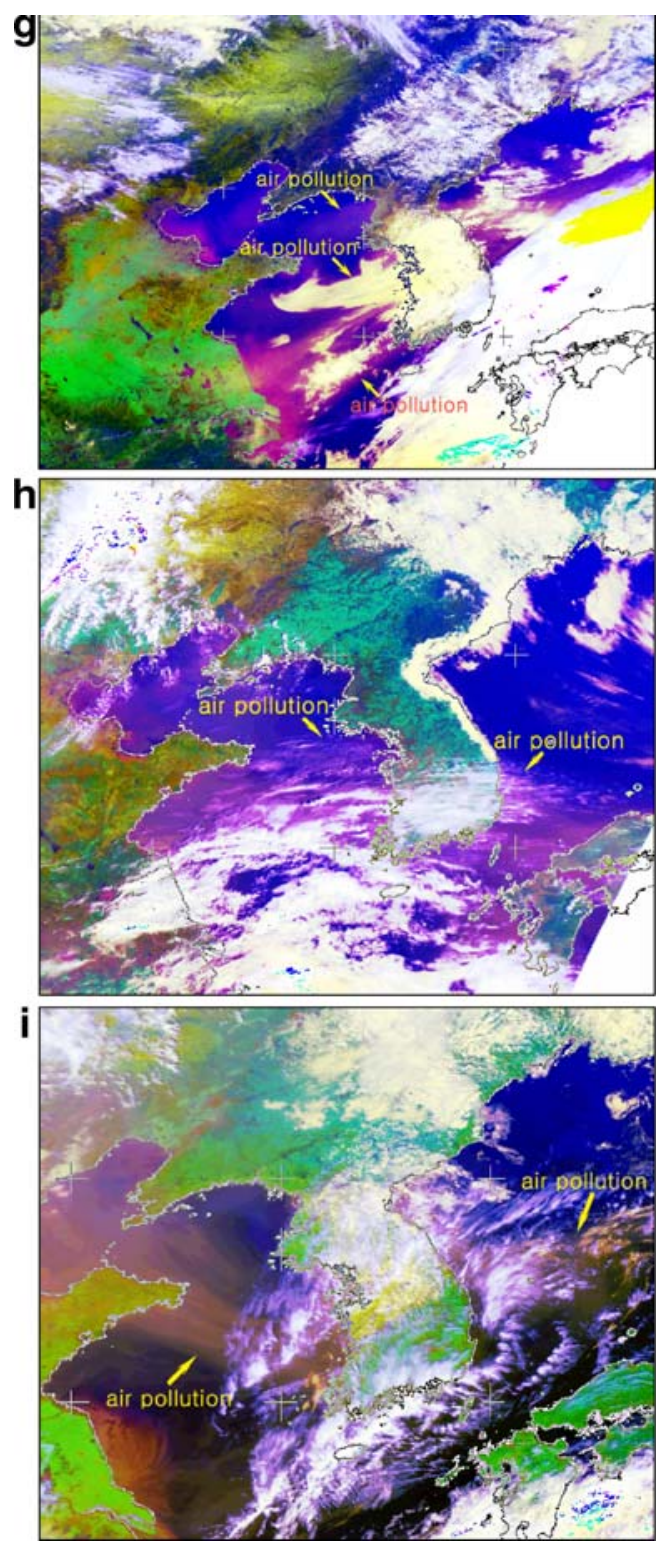

Fig. 4 (continued)

over the Korean Peninsula and moved out to the Korea East Sea and onto the western Pacific Ocean. In the satellite image, low-level smoggy clouds were also visible. Levels of dust, $\mathrm{NO}_{X}$ and $\mathrm{CO}$ were also elevated, as shown in Fig. 3c. The lowest observed visibility with the invasion of AP and smog was no more than $2.9 \mathrm{~km}$. In general, visibility was much reduced in the early morning owing to the increase in humidity and the condensation of moist air with AP by radiation cooling.

Figure 4d depicts case 6 (e in Fig. 2), which developed on 21-22 February. A massive AP (magenta) cloud from the Yellow Sea was invading the Korean Peninsula and moving out to the Korea East Sea on 21 February. After this 2-day movement, the same AP plume moved to Kyushu (Fig. 4e). Two satellite images clearly show qualitative evidence of AP.

According to Fig. 3d, levels of AP on 21 February were high and became even higher on 22 February. CO concentration was at $1,343 \mathrm{ppb}$, although, owing to the cold weather, observed $\mathrm{O}_{3}$ concentrations were lower. From 4:00 to 10:00 A.M., visibility was less than $0.9 \mathrm{~km}$, compared with $2.3 \mathrm{~km}$ at the time of maximum dust loadings. Interestingly, on 23 February, observed levels of suspended particulate matter (SPM, equivalent to PM10) in Kyushu were 50

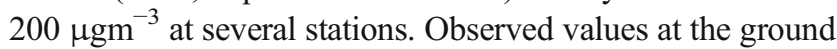
sites in both Korea and Japan also indicate quantitatively the influence of a massive AP cloud from the Yellow Sea.
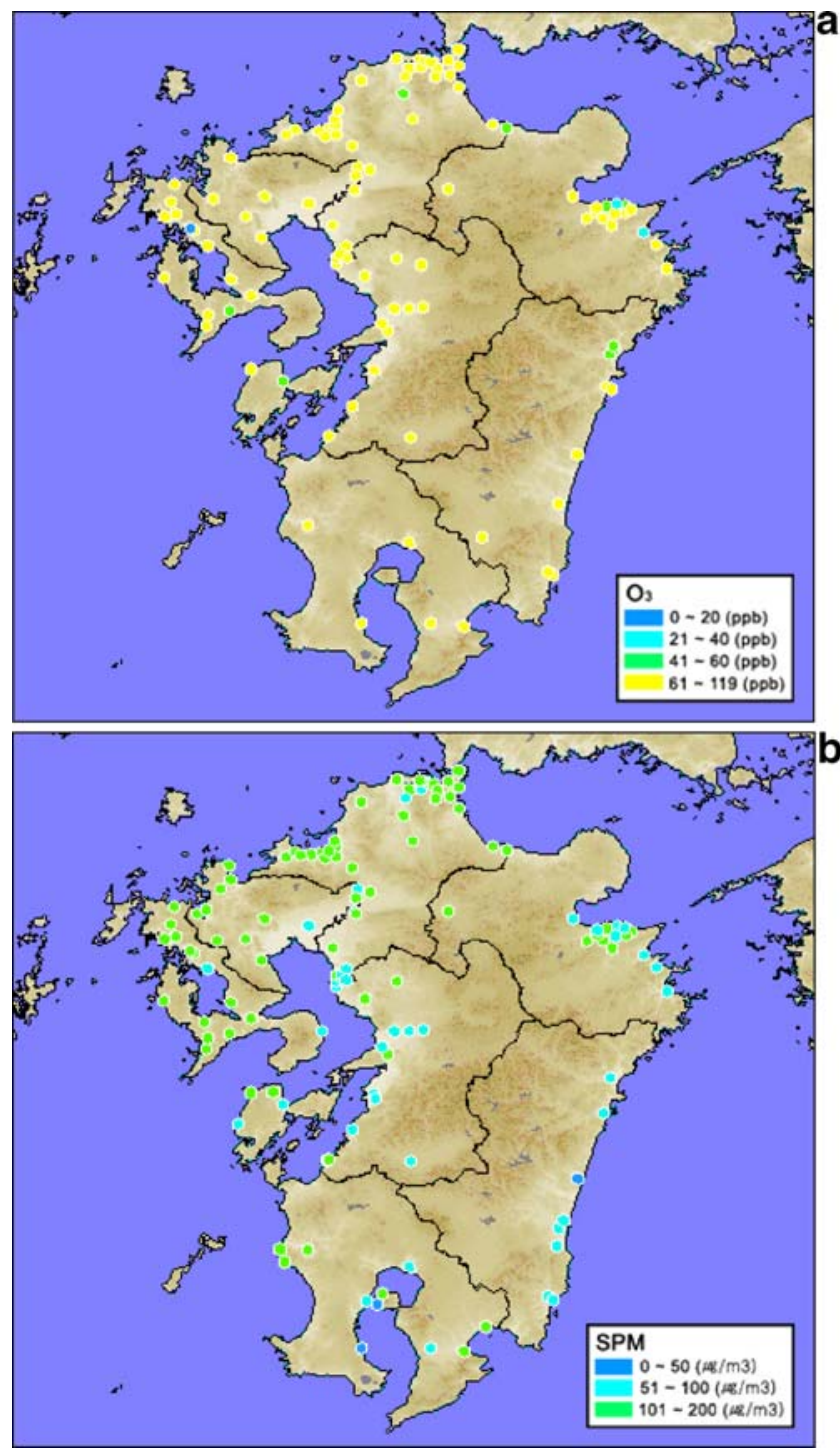

Fig. 5 a Sites observed suspended particulate matters in Kyushu, SW Japan at 1400 LST, 23 February (data from Japan Environment Agency). b For suspended particulate matters at 1400 LST, 27 May 
On 25 March, extended AP masses were over the Yellow Sea, moving toward South Korea and Kyushu, Japan (Fig. 4f). As shown in Fig. 3e and Table 2, levels of TSP, PM10, $\mathrm{O}_{3}$, and $\mathrm{CO}$ were high in central Korea, with WSW and WNW winds and trajectories. Observed visibility was under $3.8 \mathrm{~km}$ in this episode. In addition, as shown in Fig. 5a, relatively high concentrations of $\mathrm{O}_{3}$ in the warm and smoggy air were also observed in Kyushu, Japan.

On 26 and 27 March, the observed AP levels were high, with W-WSW air-parcel trajectories. TSP, PM10, and PM2.5 measured on 27 March were at 240, 215, $109{\mu g m^{-3}}^{-3}$ respectively. $\mathrm{O}_{3}$ concentrations were at $78 \mathrm{ppb}$ with $1.0 \mathrm{~km}$ visibility, and maximum $C O$ values were 1,162 and $895 \mathrm{ppb}$ during the 2 days. An AP plume (magenta) can be seen on a satellite image of 27 March in Fig. 4g. In general, a mass of AP builds up at the rear of an anticyclone. An extensive AP cloud is formed semi-periodically in the synoptic situation, and we can detect the massive plumes (magenta. reddish brown) in satellite imagery.

Figure $4 \mathrm{~h}$ includes a satellite image of 27 May, which shows large-scale transport of AP over the Yellow Sea from eastern China to South Korea and SW Japan. After the centre of a high-pressure system passed over central Korea, the measured concentrations of TSP were at $332 \mu_{\mathrm{gm}}{ }^{-3}$,

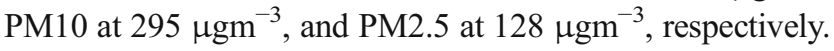
Since the ratio between TSP and PM2.5 is much lower at $38.6 \%$ than in other anthropogenic cases, we concluded that natural dust from a dust-storm was also added (Chung et al. 2003a, b). With the massive plume, a high concentration of $\mathrm{O}_{3}$ was observed at $128 \mathrm{ppb}$, and $\mathrm{CO}$ was $892 \mathrm{ppb}$ with visibility at $5.1 \mathrm{~km}$ at KCAER in Cheongwon. Maximum air temperature was $27.7^{\circ} \mathrm{C}$ with the moderate strength of a WSW trajectory (Table 2).

In addition to the present 15 anthropogenic AP episodes, we also observed five wind-blown dust storms and associated significant dust-fall events in the spring of 2007. In these cases of natural dust loadings in downwind areas, atmospheric PM10 concentrations were $253-1,211{\mu g g m^{-3}}^{-}$These are observed dust concentrations on the downstream side, where the dust sources are located between 1,500 and 4,000 km away from the sink area. More importantly, the ratio between hourly maximum TSP and PM10 ranged from $41.5 \%$ to $89.1 \%$ and that between hourly maximum TSP and PM2.5 ranged from $9.2 \%$ to $38.6 \%$ for all dust-storm episodes.

Figure 5 shows the distribution of observed SPM and $\mathrm{O}_{3}$ over Kyushu, Japan on 27 May. SPM of 100-201 $\mu$ gm $^{-3}$ was observed by the Japan Environment Agency at 100 out of 201 stations in Kyushu (Fig. 5b), and SPM of 100-199 $\mu^{-3} \mathrm{gm}^{-3}$ was measured in Shikoku at 111 out of 203 sites. Kyushu, Japan is located further downstream from China. For $\mathrm{O}_{3}$ concentrations, Kyushu observed $80-115$ ppb at 51 out of 108 sites, (Fig. 5a), while $\mathrm{O}_{3}$ in Shikoku measured $80-129$ ppb at 99 out of 124 sites. Quantitatively, this episode in Korea and
Japan was caused by the large-scale transport of extensive AP from the Yellow Sea, as shown in Fig. $4 \mathrm{~h}$.

Figure $4 i$ is a satellite image of 11 September, which shows a massive AP plume (magenta or reddish-brown) originating from western China. It was moving to the Yellow Sea, crossing the Korean Peninsula and going onward to the Korea East Sea. The satellite image shows qualitatively that the plume was clearly moving for a long distance from west to east, as indicated by the wind and trajectory (Table 2). The length of the long plume exceeded 2,000 km from eastern China to south-western Japan. A slowly moving anticyclone over China produced the stagnant AP build-ups in the Yellow Sea.

As shown in Fig. 3f, atmospheric dust loadings on 11 September were relatively high with the massive incoming plume from the Yellow Sea. TSP value was at $156 \mu \mathrm{gm}^{-3}$, PM10 at $138 \mu \mathrm{gm}^{-3}$ and PM2.5 at $109 \mu \mathrm{gm}^{-3}$. The observed $\mathrm{O}_{3}$ value was at $106 \mathrm{ppb}$ with elevated $\mathrm{CO}$ concentration at $1,049 \mathrm{ppb}$. Visibility with the plume went down to $3.8 \mathrm{~km}$ on the day of the AP episode.

\section{Discussion}

Daily consumption of energy and related emissions of AP are fairly constant, but our observations have shown that there are roughly semi-periodic ( $\sim$ weekly) build-ups of AP in the Yellow Sea region. It is found that, in general, AP concentrations vary with changes in synoptic meteorological conditions. The observed AP episodes were usually related to meteorological factors including anticyclones, winds, and airflows in the westerly region. From satellite analysis and ground-level air quality measurements, it was observed that massive extents of AP masses in the Yellow Sea do significantly impact on air quality in Korea, Japan, and over the western Pacific Ocean.

A satellite image depicts atmospheric loadings of AP and GHG vertically. It also represents the total amount of atmospheric constituents qualitatively. Meanwhile, AP measurements at KCAER represent the air quality at the ground-level atmosphere. The satellite detection of AP plumes generally agrees with the air quality values in quantitative measurements near the ground level.

It should be noted that many people suffered with colds and asthma for prolonged periods during the air pollution episodes in Korea, especially in the spring. Interestingly, when they left for a cleaner air environment in Canada, Australia, New Zealand and other countries, they found that their illness cleared up in 3 to 5 days.

It is observed that regional warming occurs both in Korea and in East Asia (Chung et al. 2004). Emissions from Asia also influence the atmospheric environment of the Arctic (Barrie 1986), and they are linked with the warming of the high Arctic. In July and August, at least half the ice covering 
the Arctic Ocean melts (Chung and Le 2004). The regional and global emissions of AP and GHG are increasing, and warming is undeniable.

\section{Concluding remarks}

It was observed that air pollution generated in China travels to the Yellow Sea and moves to the Korean Peninsula and the Japanese islands. This information was obtained by satellite and ground measurements of AP. PM10 and PM2.5 concentrations in particular were increasingly high compared with TSP concentrations in anthropogenically polluted air.

General westerly winds and weak airflows in synoptic pressure systems, e.g., on the rear side of an anticyclone, provide favorable conditions for massive transport of AP over the Yellow Sea. It was observed that, in Korea, AP episodes occur at least three or four times per month, excluding summer.

Qualitatively, satellite detection of massive AP plumes supports the results of quantitative measurements of AP at ground level. It is found that the invasion of AP plumes from the Yellow Sea does have significant impact on air quality both in Korea and SW Japan.

It is found that atmospheric loadings of anthropogenic AP contain relatively high concentrations of PM2.5. High concentrations of PM2.5 are a cause of poor visibility. It is also observed that, in a sink area located 2,000 to $4,000 \mathrm{~km}$ downstream, PM2.5 loadings are relatively less than values of TSP and PM10, even though smaller particles fly for greater distances downstream.

Toxic AP in winter and spring renders Korean children and elderly particularly susceptible to colds. The transport and build-up of large-scale AP in the downstream are a cause of environmental diseases including chronic coughing, asthma, and other respiratory disorders. There is an increase in patients with asthma and respiratory diseases.

The extent of Yellow Sea AP and anthropogenic heat release also have significant impact on climate (Chung et al. 2004) and air quality, and the abatement of atmospheric emissions to reduce climatic impact has not received much attention. International efforts are also needed for further studies on the impact of atmospheric stresses.

Acknowledgments Research funding from the Cater (2006-3103) contributed to this work. We are also grateful to Joyce Harris of NOAA for providing trajectory analysis.

Open Access This article is distributed under the terms of the Creative Commons Attribution Noncommercial License which permits any noncommercial use, distribution, and reproduction in any medium, provided the original author(s) and source are credited.

\section{References}

AFP (2007) Birth defects soar in polluted China. News 29 (October) Al-Saadi J, Szykman J, Pierce RB, Kittaka C, Neil D, Chu DA, Remer L, Gumley L, Prins E, Weinstock L, MacDonald C, Wayland R, Dimmick F, Fishman J (2005) Improving national air quality forecasts with satellite aerosol observations. Bull Am Meteor Soc 869:1249-1261

Barrie LA (1986) Arctic air pollution: an overview of current knowledge. Atmos Environ 20:643-663

Chung YS (1986) Air pollution detection by satellites. The transport and deposition of air pollutants over oceans. Atmos Environ 20:617-630

Chung YS, Le HV (1984) Detection of forest-fire smoke plumes by satellite imagery. Atmos Environ 18:2143-2151

Chung YS, Kim HS, Dulam J, Harris J (2003a) On heavy dustfall observed with explosive sandstorms in Chongwon-Chongju, Korea in 2002. Atmos Environ 37:3425-3433

Chung YS, Kim HS, Han KY, Jugder D (2003b) On East Asian sand and duststorms and associated significant dustfall observed from January to May 2001. Water Air Soil Pollut 3-2:259-277

Chung YS, Yoon MB, Kim HS (2004) On climate variations and changes observed in south Korea. Clim Change 66:151-161

Chung YS, Le HV (2004) Satellite detection of ice melt over the Arctic Ocean. Int J Remote Sens 25(2):291-296 (and front cover)

Crutzen PJ (2002) Geology of mankind. Nature 415:23

Draxler RR, Rolph GD (2003) HYSPLIT (Hybrid Single-Particle Lagrangian Integrated Trajectory) Model access via NOAA ARL READY Website (www.arl.noaa.gov/ready/hysplit4.html). NOAA Air Resources Laboratory, Silver Spring, MD

Reuter (2007) China birth defects soar due to pollution. Report, 29 October

Seinfeld JH, Carmichael G et al (2004) ACE-Asia: Regional climate and atmospheric chemical effects of Asian dust and pollution. Bull Am Met Soc 85:367-380

Tans PP, White JWC (1998) The global carbon cycle: in balance, with a little help from the plants. Science 281:183-184

Yearbook (2006) Yearbook of energy statistics. Korea Energy Economics Institute, pp 314-317 